\title{
THE DISTRIBUTION OF THE TRACE ELEMENT CONTENTS IN LIGNITE AND ASH FROM DRAMA LIGNITE DEPOSIT, USING MULTIVARIATE STATISTICAL ANALYSIS S.PANILAS ${ }^{1}$, G.HATZIYANNIS ${ }^{2}$
}

\begin{abstract}
Multivariate statistical analysis was used on existing geochemical data of the Drama lignite deposit, eastern Macedonia, Greece. Factor analysis with varimax rotation technique was applied to study the distribution of major, trace and rare earth elements in the lignite and $850^{\circ} \mathrm{C}$ lignitic ash, to find a small set of factors that could explain most of the geochemical variability. The study showed that major elements $\mathrm{Al}, \mathrm{Na}, \mathrm{K}$, contained in the lignite samples, presented high correlation with most of the trace and rare earth elements. In $850^{\circ} \mathrm{C}$ lignitic ashes major and trace elements present different redistribution. Only Al remained correlated with the trace elements $\mathrm{Co}, \mathrm{Cr}, \mathrm{Rb}, \mathrm{Ta}, \mathrm{Th}, \mathrm{Ti}, \mathrm{Sc}$ and rare earths related with inorganic matter in the lignite beds. Trace elements Fe, Mo, U, V, W, and Lu were associated with organic matter of lignite and had also been affected by the depositional environment.
\end{abstract}

\section{EYNO世H}

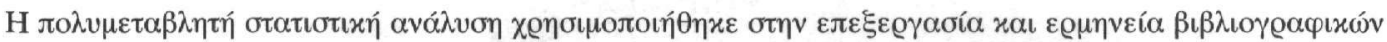

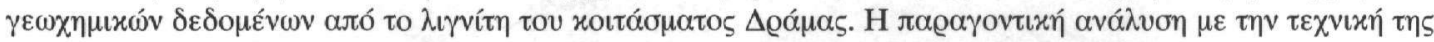

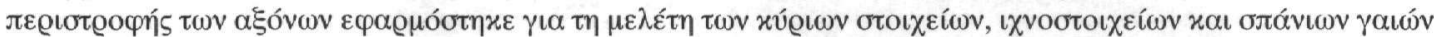

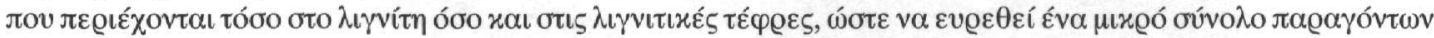

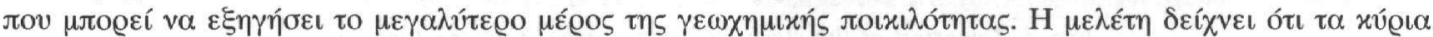

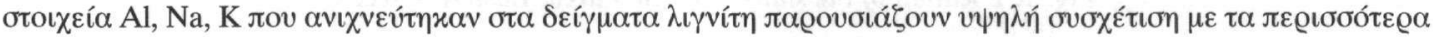

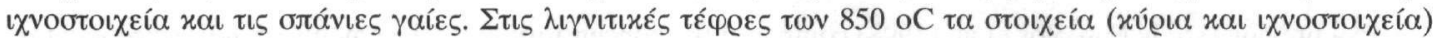

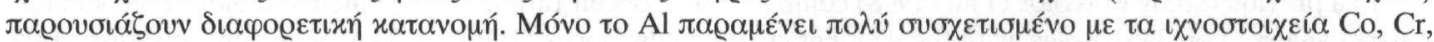

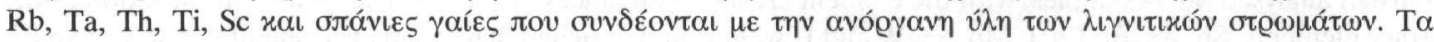

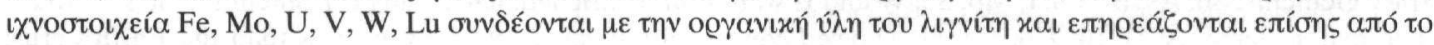

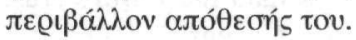

KEY WORDS: lignite, trace elements, lignite ash, Drama, multivariate analysis, factor analysis

\section{INTRODUCTION}

Factor analysis, a multivariate statistical technique, is useful for evaluating the correlation among several variables and consequently is useful for interpreting geochemical data in the lignite samples relating them to specific processes. In the present study, factor analysis was applied to geochemistry data of major, trace and rare earth elements of the Drama lignite deposit to evaluate the dominant process controlling the distribution of elements in the lignite samples and $850^{\circ} \mathrm{C}$ lignitic ashes. The chemistry and mineralogy of lignite in Drama deposit have been investigated by Filippidis et al., (1996), Foscolos et al., (1998) and Georgakopoulos (2000). The aim of this study was to point out the correlation between the 34 elements contents by the use of multivariate systems applying the method of factor analysis.

\section{STUDY AREA}

In the central plain area of the Drama basin, western of Philippi peat-lignite deposit (Melidonis 1969 ; Christanis 1983), drilling investigation executed by IGME discovered a new lignite deposit which covers an area over $90 \mathrm{Km} 2$ with $1.4^{*} 109$ tons of geological lignite reserves (Figure 1). The lignite deposit consisted mainly by

1. Public Power Corporation\Direction Lignite Researches, Ierolochiton 2866100 Drama

2. Institute of Geology and Mineral Exploration, Messogion 70,11527 Athens 
three lignite seams, which are separated by medium to fine grained clastic sediments as silts and sandy silts (Goodrarzi et al., 1990). The maximum thickness of the three lignite seams occurs in the center of the lignite deposit and exceeds 160 meters. The average moisture content is $59.4 \%$, the average ash content is $16 \%$ and the gross calorific value is $1.015 \mathrm{Kcal} / \mathrm{Kg}$ (as received basis). The mineralogy of low temperature ash consists of quartz and gypsum in all samples and feldspars, clay minerals and pyrite (Foscolos et.al. 1998). Most of the elements such as $\mathrm{As}, \mathrm{Cl}, \mathrm{Co}, \mathrm{Cr}, \mathrm{Cu}, \mathrm{Mn}, \mathrm{Mo}$ and $\mathrm{Sb}$ have relatively high concentrations in these lignites compared to trace elements content of international lignites (Foscolos et al., 1989).

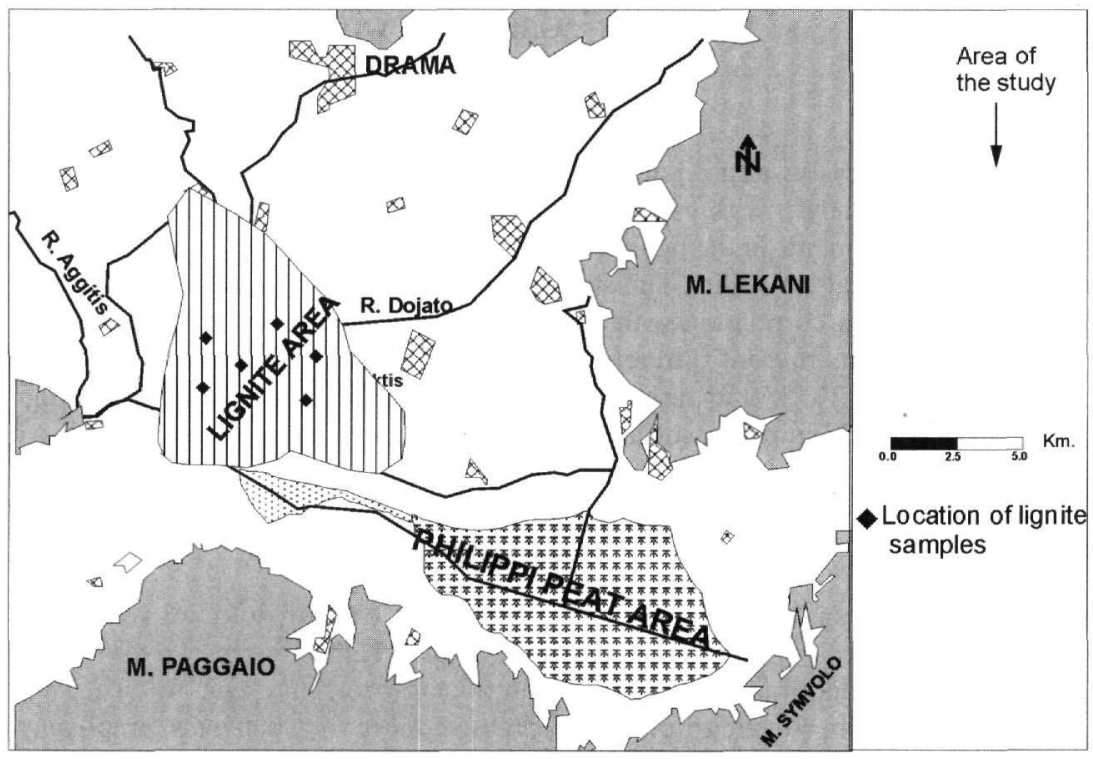

Fig. 1. Location of the study iv Drama area, Eastern Greece.

In a previous study Foscolos et al. (1998) compared the concentration of 39 elements (major, trace and rare earths) analysed on 34 samples, with the element crustal abundances (Table 1). The mean concentration of the trace elements, $\mathrm{Sb}, \mathrm{As}, \mathrm{Br}, \mathrm{Cs}, \mathrm{I}, \mathrm{Mo}, \mathrm{Se}, \mathrm{W}$ and $\mathrm{U}$ were found enriched, having an enrichment factor 2.7 to 82.7. The major elements $\mathrm{Al}, \mathrm{Br}, \mathrm{Co}, \mathrm{Cu}$, Na showed concentration values, which were less than the Earth's crust values. The enrichment of elements in the $850 \mathrm{oC}$ lignite ashes were also high as it showed an enrichment factor from 40.86 to 92.5 .

\section{PROCEDURE USED}

Statistical method of multivariate factor analysis is used in data reduction, by identifying a small number of factors which explain most of the variance observed in a much larger number of manifest variables without losing much information (Davis, 1986). This is accomplished by diagonalization of the correlation matrix of the data, which transform the original variables into uncorrelated (orthogonal) ones (weighed linear combinations of the original variables) called Principal Component (David et al., 1997). The data were standardized and arranged in correlation coefficient matrix with normal distribution in all variables. The calculated eigenvalues quantified the contribution of a factor to the total variance. Their percentages were computed. The contribution of a factor is significant when the eigenvalue is greater than one. The factor loadings were calculated by the Varimax rotation technique (Kaiser 1958) in such way that they were enclosed to $+1,0,-1$, representing positive contribution, zero and negative contribution. This technique has the effect of producing a set of uncorrelated factors in which each variable has high loadings on some factors and near-zero loadings on the others.

In the present work 34 lignite samples and $850 \mathrm{oC}$ lignitic ashes from the data of Foscolos et al., (1998) were used separately. For the calculations 34 variables were used for each sample. Statistical package SPSS 7.5 for Windows (1992) was used to carry out the calculations. 
Table 1: The enrichment ratio of elements concentration in the lignite and $850^{\circ} \mathrm{C}$ lignitic ashes. (Data from Foscolos et al. 1998)

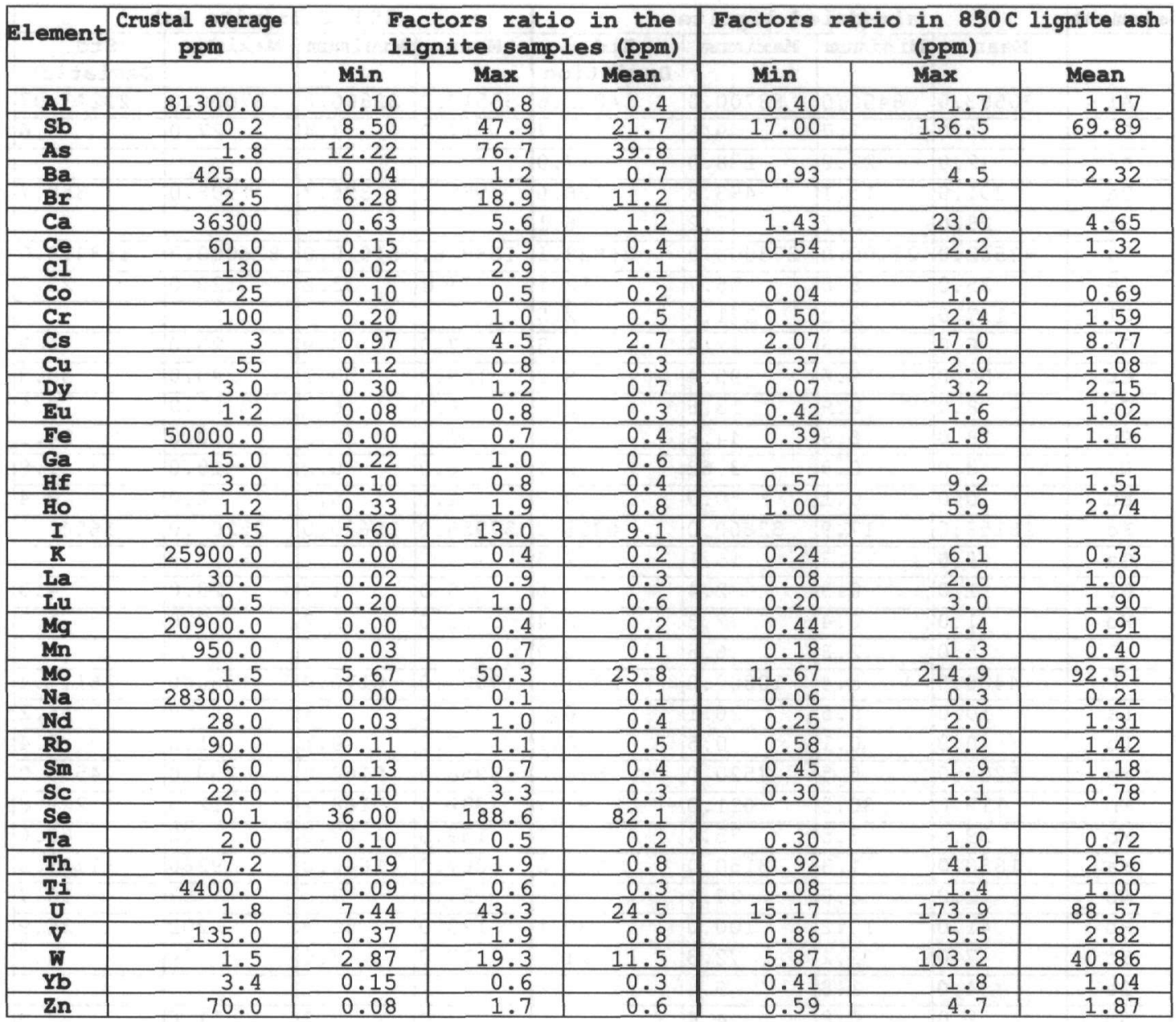

\section{RESULTS AND DISCUSSION}

Table 2 shows the mean, standard deviation, minimum and maximum values obtained from the descriptive analysis applied to determined variables. After the descriptive analysis of the variables, the construction of the correlation matrix proceeded between chemical parameters of the lignite and $850^{\circ} \mathrm{C}$ lignitic ashes. 
Table 2: Statistical data of trace elements in air-dried lignite samples and $850^{\circ} \mathrm{C}$ lignite ash (Geochemical data obtained from Foscolos et al. 1998)

\begin{tabular}{|c|c|c|c|c|c|c|c|c|}
\hline element & \multicolumn{4}{|c|}{ air-dried lignite } & \multicolumn{4}{|c|}{$850^{\circ} \mathrm{C}$ lignite ash } \\
\hline & Mean & Minimum & Maximum & $\begin{array}{c}\text { Std. } \\
\text { Deviation }\end{array}$ & Mean & Minimum & Maximum & $\begin{array}{c}\text { Std. } \\
\text { Deviation }\end{array}$ \\
\hline $\mathrm{Al}$ & 30583.0 & 8450.0 & 63700.0 & 14012.6 & 95513.0 & 32800.0 & 137000.0 & 29243.07 \\
\hline $\mathrm{Sb}$ & 4.0 & 1.7 & 9.6 & 1.7 & 14.0 & 3.4 & 27.0 & 6.6 \\
\hline As & 72.0 & 22.0 & 138.0 & 27.0 & & & & \\
\hline $\mathrm{Ba}$ & 291.0 & 15.1 & 493.8 & 106.6 & 985.0 & 396.7 & 1908.0 & 358.7 \\
\hline $\mathrm{Br}$ & 28.0 & 15.7 & 47.2 & 6.1 & & & & \\
\hline $\mathrm{Ca}$ & 43562.0 & 22700.0 & 203000.0 & 36828.1 & 168928. & 51910.0 & 836000.0 & 153419.0 \\
\hline $\mathrm{Ce}$ & 25.0 & 8.8 & 55.7 & 12.1 & 790 & 32.2 & 129.0 & 22.9 \\
\hline $\mathrm{Cl}$ & 137.0 & 2.3 & 371.0 & 82.5 & & & & \\
\hline Co & 6.0 & 2.5 & 12.4 & 2.3 & 17.0 & 0.9 & 25.0 & 4.9 \\
\hline $\mathrm{Cr}$ & 50.0 & 19.6 & 95.4 & 19.2 & 159.0 & 50.2 & 240.0 & 38.3 \\
\hline $\mathrm{Cs}$ & 8.0 & 2.9 & 13.6 & 2.9 & 26.0 & 6.2 & 51.0 & 8.6 \\
\hline $\mathrm{Cu}$ & 18.0 & 6.8 & 44.6 & 9.2 & 60.0 & 20.3 & 110.0 & 24.1 \\
\hline Dy & 2.0 & 0.9 & 3.62 & 0.7 & 6.0 & 0.2 & 10.0 & 1.8 \\
\hline Eu & 0.0 & 0.1 & 0.9 & 0.2 & 1.0 & 0.5 & 2.0 & 0.4 \\
\hline $\mathrm{Fe}$ & 18158.0 & 17.9 & 32600.0 & 6333.0 & 57955.0 & 19620.0 & 92200.0 & 16542.5 \\
\hline $\mathrm{Ga}$ & 9.0 & 3.3 & 15.1 & 2.9 & & & & \\
\hline Hf & 1.0 & 0.3 & 2.4 & 0.6 & 5.0 & 1.7 & 28.0 & 4.3 \\
\hline Ho & 1.0 & 0.4 & 2.3 & 0.4 & 3.0 & 1.2 & 7.0 & 1.3 \\
\hline I & 5.0 & 2.8 & 6.5 & 0.9 & & & & \\
\hline $\mathrm{K}$ & 4480.0 & 5.4 & 10800.0 & 2361.3 & 19007.0 & 6170.0 & 158000 & 26117.4 \\
\hline $\mathrm{La}$ & 10.0 & 0.5 & 26.1 & 6.7 & 30.0 & 2.5 & 59 & 15.2 \\
\hline $\mathrm{Lu}$ & 0.0 & 0.1 & 0.5 & 0.1 & 1.0 & 0.1 & 1.5 & 0.4 \\
\hline $\mathrm{Mg}$ & 5205.0 & 5.5 & 7520.0 & 978.0 & 18958.0 & 9160.0 & 29910 & 4555.0 \\
\hline Mn & 119.0 & 30.3 & 621.0 & 97.7 & 382.0 & 168.2 & 1273 & 229.8 \\
\hline Mo & 39.0 & 8.5 & 75.4 & 15.1 & 139.0 & 17.5 & 322 & 69.6 \\
\hline $\mathrm{Na}$ & 1830.0 & 1.3 & 3150.0 & 751.0 & 6067.0 & 1640.0 & 9260 & 1733.3 \\
\hline $\mathrm{Nd}$ & 12.0 & 0.8 & 27.0 & 5.5 & 37.0 & 7.0 & 57 & 10.7 \\
\hline $\mathrm{Rb}$ & 41.0 & 10.2 & 100.0 & 20.1 & 128.0 & 51.9 & 202 & 36.9 \\
\hline Sc & 7.0 & 2.1 & 72.3 & 11.7 & 17.0 & 6.5 & 24 & 4.7 \\
\hline $\mathrm{Se}$ & 4.0 & 1.8 & 9.4 & 1.8 & & & & \\
\hline $\mathrm{Sm}$ & 2.0 & 0.8 & 4.4 & 1.0 & 7.0 & 2.7 & 11.6 & 2.0 \\
\hline $\mathrm{Ta}$ & 1.0 & 0.2 & 0.9 & 0.2 & 1.0 & 0.6 & 2 & 0.4 \\
\hline Th & 6.0 & 1.4 & 13.9 & 3.0 & 19.0 & 6.6 & 29.5 & 6.1 \\
\hline $\mathrm{Ti}$ & 1428.0 & 390.0 & 2760.0 & 641.7 & 4382.0 & 346.0 & 6280 & 1457.7 \\
\hline $\mathrm{U}$ & 44.0 & 13.5 & 78.0 & 17.0 & 159.0 & 27.3 & 313 & 79.7 \\
\hline $\mathrm{V}$ & 112.0 & 49.9 & 252.0 & 42.7 & 381.0 & 116.2 & 748 & 152.3 \\
\hline $\mathrm{W}$ & 17.0 & 4.3 & 29.0 & 5.5 & 61.0 & 8.8 & 155 & 28.9 \\
\hline $\mathrm{Yb}$ & 1.0 & 0.5 & 2.1 & 0.4 & 4.0 & 1.4 & 6.1 & 1.0 \\
\hline $\mathrm{Zn}$ & 40.0 & 5.4 & 120.0 & 24.2 & 131.0 & 41.6 & 331 & 59.9 \\
\hline
\end{tabular}

In the lignite samples, significant correlation between the major elements (Al-K: 0.93), (Al-Na: 0.76), (Na$\mathrm{K}: 0.85)$ can be recognized. These elements were correlated with most of the trace elements and rare earth's. It is noted that $\mathrm{Mg}$ and $\mathrm{Ca}$ presented low correlation's with all the other elements.

Correlation coefficient matrix at $850^{\circ} \mathrm{C}$ lignite ash showed that the ash content presented negative correlation coefficient with $\mathrm{Mg}(-0.72)$, Mo (-0.82), Sb (-0.68), U (-0.83), V (-0.54), and W (-0.78). These elements showed that their concentration increased with decreasing ash content and can therefore be evaluated as associated with the organic matter of the lignite. The elements Th (0.53), Ce (0.52), La (0.70), Ta (0.54), Ti (0.52)showed low to medium positive correlation with ash content and can be related with the inorganic mineral in the lignite. The major element $\mathrm{Al}$ presented positive correlation with the ash content $(0.42)$ and high positive correlation with the trace elements. Major elements as $\mathrm{Na}, \mathrm{Ca}, \mathrm{K}, \mathrm{Cu}, \mathrm{Mn}$ are poorly correlated with trace and rare earth 
elements and didn't show any preference towards minerals or organic matter.

Factor matrix obtained by Principal Component Analysis was subjected to a Varimax rotation. The extracted factors with eigenvalues greater than one were considered in the interpretation following varimax rotation.

Table 3 shows eigenvalues and variance explained (\%) from the first five extracted axes of elements in the lignite samples accounted for about $87 \%$ of total variance (eigenvalues greater than one) and Table 4 shows seven eigenvalues explained $87.7 \%$ of the total variance from the $850 \mathrm{oC}$ lignitic ashes.

Table 3. Results of the Varimax rotated analysis in lignite samples

\begin{tabular}{|c|c|c|c|}
\hline Factor & Eigenvalues & $\mathbf{8}$ of & Cumulative \\
\hline 1 & 17.37 & 51.08 & 51.08 \\
\hline 2 & 5.09 & 14.97 & 66.04 \\
\hline 3 & 4.08 & 11.99 & 78.03 \\
\hline 4 & 1.66 & 4.87 & 82.91 \\
\hline 5 & 1.40 & 4.11 & 87.02 \\
\hline
\end{tabular}

Table 4. Results of Varimax rotated analysis in $850 \mathrm{oC}$ lignitic ashes

\begin{tabular}{|c|c|c|c|}
\hline Factor & Eigenvalues & $\mathbf{8}$ of & Cumulative \\
\hline 1 & 12.3 & 36.2 & 36.2 \\
\hline 2 & 5.4 & 16.0 & 52.2 \\
\hline 3 & 3.9 & 11.4 & 63.6 \\
\hline 4 & 2.5 & 7.4 & 71.0 \\
\hline 5 & 2.1 & 6.2 & 77.2 \\
\hline 6 & 2.0 & 5.8 & 83.0 \\
\hline 7 & 1.6 & 4.6 & 87.7 \\
\hline
\end{tabular}

\section{Major and trace elements in lignite samples}

Table 5 summarizes the results obtained from rotated factor analysis loadings of variables in lignite samples. It shows that $78 \%$ of the total variance is attributable to the first three factors and only $9 \%$ of the total variance in the two minor factors.

Table 5: Varimax rotated factor matrix of elements in the lignite samples

\begin{tabular}{|c|c|c|c|c|c|}
\hline Variable & VF1 & VE2 & VE3 & VE4 & VE5 \\
\hline Al & 0.94 & 0.04 & 0.30 & 0.05 & 0.00 \\
\hline Sb & 0.10 & 0.92 & 0.06 & - & 0.08 \\
\hline $\mathrm{Ba}$ & 0.43 & 0.66 & 0.29 & 0.10 & -0.16 \\
\hline $\mathrm{Ca}$ & -0.22 & -0.25 & -0.35 & 0.04 & 0.06 \\
\hline $\mathrm{Ce}$ & 0.94 & 0.01 & 0.25 & 0.60 & 0.03 \\
\hline Co & 0.91 & 0.17 & 0.20 & 0.08 & 0.07 \\
\hline Cr & 0.87 & 0.36 & 0.22 & 0.14 & 0.15 \\
\hline Cs & 0.75 & 0.35 & 0.05 & - & 0.07 \\
\hline $\mathrm{Cu}$ & 0.43 & 0.27 & 0.79 & 0.10 & -0.01 \\
\hline Dy & 0.91 & 0.25 & 0.28 & 0.00 & -0.01 \\
\hline Eu & 0.94 & 0.05 & 0.19 & 0.02 & 0.00 \\
\hline $\mathrm{Fe}$ & 0.56 & 0.38 & 0.29 & 0.01 & 0.11 \\
\hline Ga & 0.78 & 0.12 & 0.47 & - & -0.04 \\
\hline Hf & 0.85 & -0.08 & -0.13 & 0.33 & -0.19 \\
\hline Ho & 0.54 & 0.03 & -0.22 & - & -0.44 \\
\hline$\pi$ & 0.85 & -0.10 & 0.06 & 0.17 & 0.32 \\
\hline Ina & 0.95 & -0.20 & 0.19 & - & 0.03 \\
\hline In & 0.37 & 0.65 & 0.42 & 0.22 & 0.15 \\
\hline $\mathrm{Ma}$ & 0.23 & -0.11 & -0.12 & - & 0.90 \\
\hline $\mathrm{M}$ in & 0.30 & 0.24 & 0.85 & - & 0.04 \\
\hline Mo & -0.12 & 0.81 & -0.36 & 0.07 & -0.04 \\
\hline $\mathrm{Na}$ & 0.80 & 0.19 & -0.28 & 0.18 & 0.08 \\
\hline Nd & 0.88 & 0.14 & 0.30 & 0.09 & 0.05 \\
\hline $\mathbf{R b}$ & 0.96 & -0.03 & 0.03 & 0.08 & 0.03 \\
\hline Sc & 0.39 & -0.20 & -0.11 & 0.75 & 0.00 \\
\hline $\mathrm{Sm}$ & 0.93 & 0.19 & 0.26 & 0.06 & 0.06 \\
\hline $\mathrm{Ta}$ & 0.94 & 0.02 & 0.17 & 0.25 & -0.04 \\
\hline Th & 0.89 & 0.09 & 0.43 & 0.02 & 0.01 \\
\hline$T i$ & 0.94 & 0.02 & 0.16 & 0.18 & 0.06 \\
\hline U & -0.17 & 0.93 & 0.01 & - & -0.23 \\
\hline V & 0.32 & 0.84 & 0.34 & - & 0.01 \\
\hline in & -0.13 & 0.37 & -0.70 & $=$ & 0.24 \\
\hline $\mathbf{Y b}$ & 0.88 & 0.25 & 0.29 & 0.04 & 0.01 \\
\hline $\mathrm{Zn}$ & 0.77 & 0.22 & 0.50 & 0.06 & 0.13 \\
\hline
\end{tabular}


The first rotated factor VF1, which explained $51 \%$ of the total variance, presented high positive loadings for major elements $\mathrm{Al}, \mathrm{Na}, \mathrm{K}$, trace elements $\mathrm{Zn}, \mathrm{Co}, \mathrm{Cr}, \mathrm{Ti}, \mathrm{Cs}, \mathrm{Rb}, \mathrm{Ta}$, Th and rare earths $\left({ }^{*} \mathrm{Ce},{ }^{*} \mathrm{Dy},{ }^{*} \mathrm{Eu},{ }^{*} \mathrm{La}\right.$, ${ }^{*} \mathrm{Nd},{ }^{*} \mathrm{Sm}$ and ${ }^{*} \mathrm{Yb}$ ). This factor can be associated with detrital constituents in lignite resulting from the surrounding rocks of Drama basin.

The second factor VF2, which explained $15 \%$ of the total variance, presented high loading in the trace elements $\mathrm{Sb}, \mathrm{Mo}, \mathrm{V}$ and $\mathrm{U}$ and probably could be associated with inorganic constituents deposited syngenetically with the organic matter of lignite.

The third factor VF3 that explained $12 \%$ of the total variance showed that W played an antagonistic role to the $\mathrm{Cu}$ associated to $\mathrm{Mn}$.

From the graphical representation of the first two rotated factors VF1-VF2 (Figure 2), which explain $66 \%$ of total variance, it is observed that factor VF2 is characterized by high loadings in the elements Mo, U, V, and Sb. These variables are positively located closely in VF2 coordinate system. Intermediate affinity between the factors VF1 (characterized by detrital elements) and factor VF2 (characterized by organic constituents) present the elements $\mathrm{Fe}, \mathrm{Cu}$ and $\mathrm{Mn}$.

Plot of rotated factor VF1-VF3 (Figure 3) shows that $\mathrm{Mn}$ and $\mathrm{Cu}$ presented positive high loadings in the factor VF2 with W negative correlation in the same factor.

The other two minor factors VF4 and VF5 explained only $4.9 \%$ and $4.1 \%$ of the total variance and were characterized by high loadings of $\mathrm{Ca}$ and $\mathrm{Mg}$ respectively.

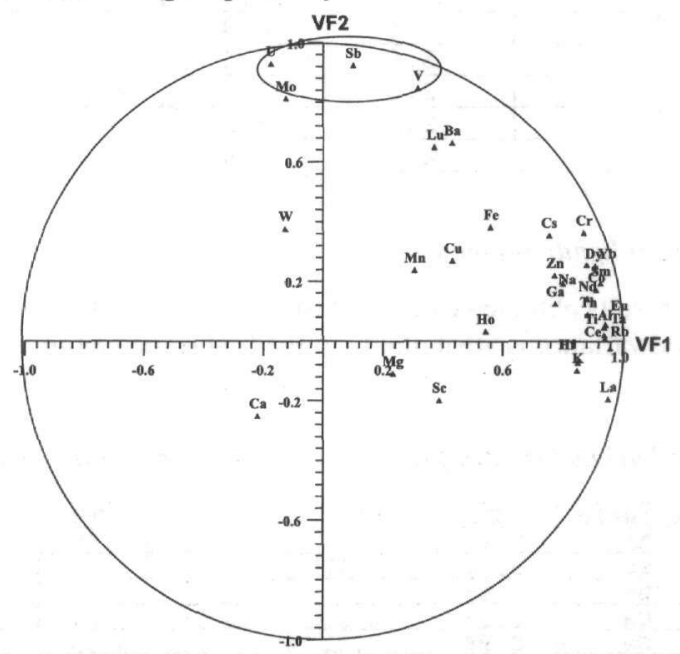

Fig. 2 Plot of the first two rotated factor weights 1-2 in lignite elements

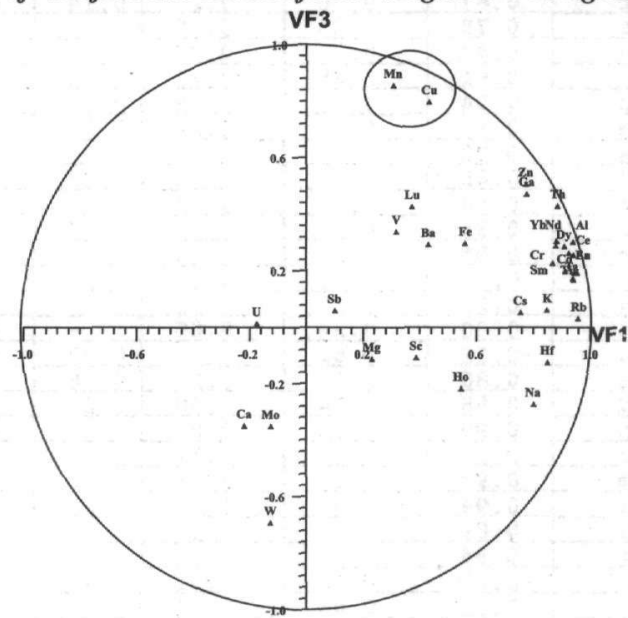

Fig. 3 Plot of the first two rotated factor weights 1-3 in lignite elements 


\section{Major and trace elements in $850^{\circ} \mathrm{C}$ lignite ash}

Table 6 shows that $63 \%$ of the total variance is attributable to the first three factors and the other four minor factors explained $24.4 \%$ of the total variance.

Table 6: Varimax rotated factor matrix in 850 oC ash elements

\begin{tabular}{|c|c|c|c|c|c|c|c|}
\hline Variable & VF1 & VE2 & VF3 & VF4 & VF5 & VF6 & VE7 \\
\hline Al & 0.87 & -0.24 & 0.23 & 0.20 & 0.00 & 0.12 & -0.07 \\
\hline $\mathrm{Ba}$ & 0.23 & 0.30 & 0.72 & 0.20 & 0.10 & 0.10 & 0.33 \\
\hline $\mathrm{Ce}$ & 0.90 & -0.04 & -0.08 & 0.20 & 0.00 & -0.30 & -0.03 \\
\hline Co & 0.76 & 0.27 & -0.10 & -0.10 & -0.20 & 0.20 & 0.08 \\
\hline $\mathrm{Cr}$ & 0.88 & 0.13 & 0.16 & 0.00 & -0.10 & 0.10 & -0.20 \\
\hline Cs & 0.31 & 0.14 & 0.83 & 0.10 & -0.10 & -0.11 & 0.08 \\
\hline $\mathrm{Cu}$ & 0.38 & 0.22 & -0.09 & 0.67 & $-0, .90$ & 0.21 & -0.28 \\
\hline Dy & 0.77 & 0.44 & 0.23 & 0.15 & 0.10 & 0.00 & 0.21 \\
\hline $\mathbf{E u}$ & 0.81 & -0.08 & -0.05 & 0.28 & 0.05 & -0.10 & 0.29 \\
\hline $\mathbf{F e}$ & 0.24 & 0.77 & 0.08 & 0.15 & -0.04 & 0.29 & 0.17 \\
\hline Hf & -0.07 & 0.27 & 0.04 & 0.15 & -0.05 & 0.88 & 0.05 \\
\hline Ho & 0.01 & 0.06 & 0.27 & -0.22 & -0.10 & 0.07 & 0.85 \\
\hline $\mathbf{K}$ & 0.18 & -0.07 & -0.08 & -0.05 & 0.96 & 0.03 & -0.10 \\
\hline Ia & 0.80 & -0.29 & -0.27 & 0.18 & 0.10 & -0.27 & 0.17 \\
\hline Lu & 0.22 & 0.87 & 0.13 & 0.21 & 0.04 & 0.09 & -0.18 \\
\hline Mg & -0.14 & 0.46 & 0.66 & -0.20 & -0.23 & -0.09 & -0.06 \\
\hline Mn & 0.13 & 0.21 & 0.43 & 0.68 & 0.11 & 0.32 & 0.11 \\
\hline Mo & -0.36 & 0.76 & 0.27 & -0.36 & -0.10 & 0.00 & -0.01 \\
\hline $\mathrm{Na}$ & 0.32 & 0.11 & 0.55 & -0.07 & 0.10 & 0.49 & -0.04 \\
\hline Nd & 0.86 & 0.00 & 0.02 & 0.24 & -0.13 & 0.01 & 0.05 \\
\hline $\mathbf{R b}$ & 0.78 & -0.21 & -0.11 & -0.35 & -0.10 & 0.16 & -0.17 \\
\hline $\mathrm{Sb}$ & -0.12 & 0.53 & 0.64 & 0.04 & -0.03 & 0.39 & 0.18 \\
\hline Sc & 0.92 & 0.05 & 0.21 & 0.17 & 0.01 & 0.11 & 0.04 \\
\hline $\mathrm{Ca}$ & -0.31 & -0.02 & -0.06 & 0.00 & 0,90 & -0.10 & 0.02 \\
\hline $\mathrm{Sm}$ & 0.93 & 0.14 & 0.11 & 0.18 & 0.03 & -0.07 & 0.11 \\
\hline $\mathrm{Ta}$ & 0.84 & -0.25 & 0.03 & -0.02 & -0.08 & 0.15 & -0.23 \\
\hline Th & 0.90 & -0.15 & 0.10 & 0.30 & 0.10 & 0.02 & -0.08 \\
\hline$T i$ & 0.84 & -0.32 & 0.25 & -0.50 & 0.04 & 0.10 & -0.21 \\
\hline $\bar{U}$ & $-0,20$ & 0.74 & 0.51 & $-0,05$ & -0.13 & 0.24 & 0.22 \\
\hline $\mathbf{v}$ & 0.22 & 0.66 & 0.48 & 0.19 & $-0,01$ & 0,40 & 0,20 \\
\hline พ & -0.51 & 0.62 & 0.21 & -0.35 & -0.14 & -0.12 & -0.07 \\
\hline Yb & 0.85 & 0,39 & 0.02 & 0.13 & -0.04 & -0.03 & 0.15 \\
\hline $\mathbf{Z n}$ & 0.38 & $-0,29$ & -0.10 & 0.72 & -0.03 & -0.14 & -0.27 \\
\hline
\end{tabular}

For VF1 the elements $\mathrm{Al}, \mathrm{Co}, \mathrm{Cr}, \mathrm{Rb}, \mathrm{Ta}, \mathrm{Th}, \mathrm{Ti}, \mathrm{Sc}$ and rare earths $\left({ }^{*} \mathrm{Yb},{ }^{*} \mathrm{Ce},{ }^{*} \mathrm{Dy},{ }^{*} \mathrm{Eu},{ }^{*} \mathrm{La},{ }^{*} \mathrm{Nd}\right.$, and $\left.{ }^{*} \mathrm{Sm}\right)$ had high loadings $(>0,8)$. Factor VF1 accounted for $36 \%$ of total variance in $850 \mathrm{oC}$ ash contents, whereas factor VF1 in the lignite elements accounted for $51 \%$ of the total variance. The difference may reflect the redistribution of major elements $\mathrm{Na}$ and $\mathrm{K}$ in lignitic ashes. Na presented low loadings in all factors, while $\mathrm{K}$ presented high ones (0.96) at factor VF5 correlated with Ca.

The second factor (VF2) explained $16 \%$ of the total variance and showed high positive loadings in trace elements Fe, Mo, U, V, W, Lu. This factor is characterized as having an organophilic affinity and it is associated with lignite macerals related also to environmental effect.

The common plotting factors are projected on the plane VF1 and VF2 (Figure 4) and the contributions of the elements as well as the sign of their loadings on these factors are listed on Table 6.

The third factor (VF3) explains 11\% of the total variance and showed high positive loading in the element $\mathrm{Mg}$ and trace elements $\mathrm{Ba}, \mathrm{Sb}$ and $\mathrm{Cs}$ and may be analogous to factor (VF4) associated with major elements $\mathrm{Cu}$, $\mathrm{Mn}$ and $\mathrm{Zn}$ (Figure $5 \& 6$ ). Factor VF5 showed moderate loadings at $\mathrm{Ca}(0.90)$ and $\mathrm{K}(0.96)$. The other two factors explained less than $10 \%$ of total variance. 


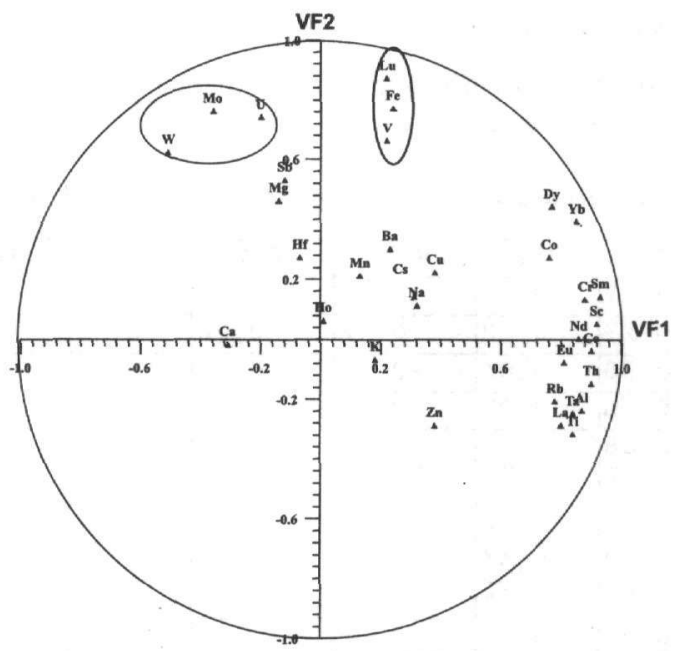

Fig. 4 Plot of the first two rotated factor weights 1-2 in $850^{\circ} \mathrm{C}$ lignite ashes

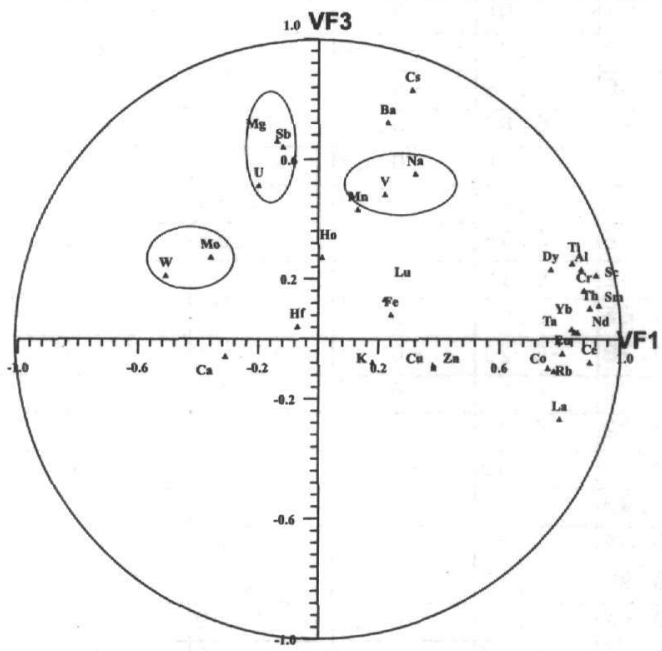

Fig. 5 Plot of the first two rotated factor weights $1-3$ in $850^{\circ} \mathrm{C}$ lignite ashes

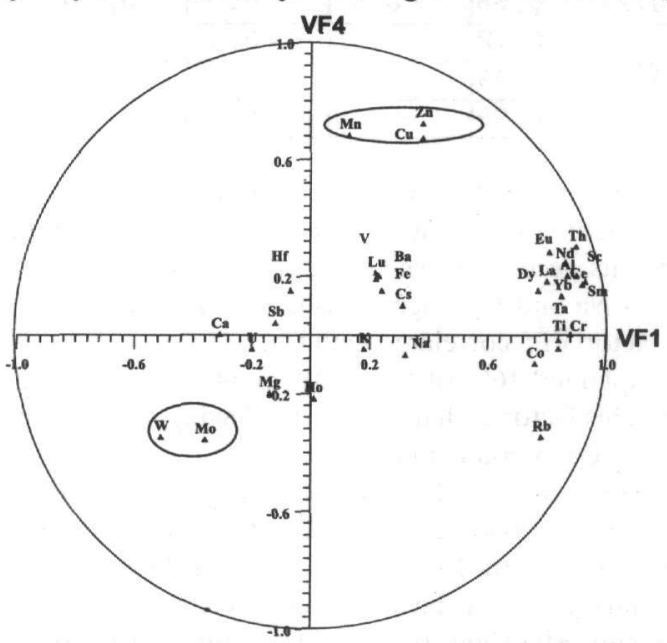

Fig. 6 Plot of first two rotated factor weights $1-4$ in $850^{\circ} \mathrm{C}$ lignite ashes 


\section{CONCLUSIONS}

Factor analysis with varimax rotation technique reduced the 34 variables in the lignite samples to five significant factors that explain $87.02 \%$ of the total variance. The first factor namely VF1 $(51.02 \%$ of the total variance), can be associated with detrital constituents in lignite resulting from the surrounding rocks of Drama basin.

From varimax rotation in the $850^{\circ} \mathrm{C}$ lignitic ashes seven significant factors were extracted that explain $87.7 \%$ of total variance. Factor VF1 accounted for $36 \%$ of total variance in $850 \mathrm{oC}$ ashes contents, whereas factor VF1 in the lignite elements accounted for $51 \%$ of the total variance. This difference could reflect the redistribution of major elements $\mathrm{Na}$ and $\mathrm{K}$ in lignitic ashes. $\mathrm{Na}$ presented low loadings in all factors while $\mathrm{K}$ presented high loadings (0.96) at factor VF5 correlated with $\mathrm{Ca}$.

\section{REFERENCES}

CHRISTANIS, K. 1983. Genese und Fazies der Torf-Lagerstatte von Philippi (Griechisch-Mazedonien) als Beispiel der Entstehung einer Braunkohlen-Lagerstatte von stark telmatischen Typ. PhD Thesis, Braunschwig, 170 pp.

DAVIS, J.C., 1986. Statistics and Data Analysis in Geology. John Wiley and Sons, New York, 646 pp.

DAVID, M., DAGBERT, M. \& BEAUCHEMIN Y. 1997. Statistical analysis in Geology: Correspondence analysis method. Quarterly of the Colorado School of mines. Vol. 72, Nb1, 21-46.

FILIPPIDIS, A., GEORGAKOPOULOS, A., KASSOLI-FOURNARAKI, A., MISAELIDES, P., YIAKKOUPIS P. \& BROUSSOULIS J., 1996. Trace element contents in composited samples of three lignite seams from the central part of the Drama lignite deposit, Macedonia, Greece. Inter. J. Coal Geol., 29, 219-234.

FOSCOLOS, A., GOODARZI, F., KOUKOUZAS C. \& HATZIYANNIS, G. 1989. Reconnaissance study of mineral matter and trace elements in Greek lignites. Chemical Geology 76, 107-130.

FOSCOLOS, A., GOODARZI, F., KOUKOUZAS C. \& HATZIYANNIS, G. 1998. Assessment of environmental impact of coal exploration and exploitation in the Drama basin, Northeasten Greek-Macedonia. Energy Sources, 20,795-820.

GEORGAKOPOULOS, A. 2000. The Drama lignite deposit, Northern Greece. Insights from Traditional Coal Analyses, Rock-Eval Data, and Natural Radionuclides Concentrations. Energy Sources 22, 497-513.

GOODARZI,F., GENTIS T., \& YIAKKOUPIS P., 1990. Petrographic characteristics and depositional environment of Greek lignites: I Drama Basin, northern Greece. Journal of Coal Quality 9(1):26-37.

MELIDONIS N., 1969. The peat-lignite deposit of Philippi (Macedonia, Greece). Geol. Geophys. Res. XIII N.3, 250 pp. (In Greek, English abstract).

KAISER F., 1958. The varimax criteria for analytical rotation in factor analysis. Psychometrika, 20, 187-200.

SPSS Inc. 1996. SPSS 7.5 Categories, SPSS Inc., Chicago, 209 pp. 